\title{
化膿性膝関節炎に対する開放運動療法の経験
}

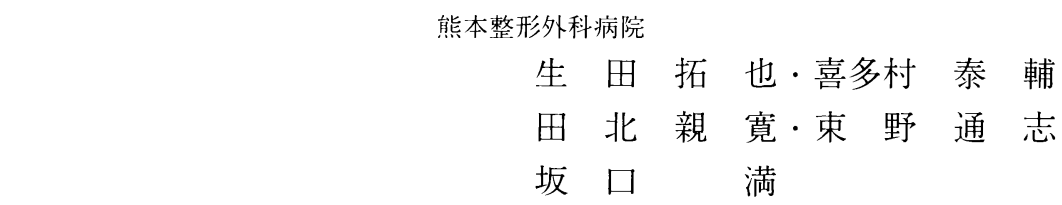

\section{Functional Treatment of Pyogenic Arthritis of Knee}

\author{
Takuya Ikuta, Taisuke Kitamura, Chikahiro Takita, \\ Michishi Tsukano and Mitsuru Sakaguchi \\ Kumamoto Orthopaedic Hospital
}

\begin{abstract}
Fifteen patients with pyogenic arthritis of the knee were treated by open arthrotomy and early passive motion. All patients healed without subsequent operations. Of these patients, two had excellent results, eleven had good results, and two had fair results according to the modified Ballard's evaluation method.
\end{abstract}

This is a useful and simple method for treating pyogenic arthritis of the knee.

Key words : pyogenic arthritis (化膿性関節炎), knee (膝), arthrotomy (関節切開術), functional treatment（運動療法）

\section{I .はじめに}

化膿性膝関節炎は治療の時期や方法を誤ると機能障 害を残すことが少なくない，我々は，関節切開排膿後, 創開放のまま直後より運動療法を行い良好な結果を得 ているので報告する。

\section{II. 手術方 法}

原則的に腰麻下にて行っているが, 全身状態が良く ない場合や，診断当日に緊急で手術を行う場合は局麻 下に行うこともある。

皮切は滕蓋骨の両側に滕蓋骨とほぼ同じ長さに加え, 同部位で retinaculum, 関節包を切開し関節内に達 する．関節内を充分に洗浄し関節軟骨や滑膜の状態を 確認後，止血を行い，創は開放したままガーゼを当て て弾力包带で王迫固定を行う. 滑膜切除は当初の数例 に行ったが, 出血のコントロールが難しくなることも あり現在は行っていない.

\section{III. 術 後 療 法}

術直後より CPMにて可動域訓練を開始し，翌日よ り午前, 午後 1 時間ずつ $\mathrm{CPM}$ にて可動域訓練を続け る. 創部からの滲出液が減少する術後 $2 \sim 3$ 週より荷 重を開始する。創部のガーゼは毎日交換し, ESR, CRP が正常化するまで抗生剂投与を静注もしくは経 ロで続ける。

\section{IV. 対}

象

症例は 1991 年 5 月 1998 年 3 月までの 15 例 16 膝 であり, 性別は男性 2 例, 女性 13 例, 年齢は $7 \sim 88$ 歳, 平均 68.9 歳であった。術後経過観察期間は 5 〜84 ケ月, 平均 34 ケ月であった。

発症前に原疾患が存在した症例は 12 例で, 変形性 膝関節症が 10 例（このうち 1 例は人工膝関節置換術 後)，慢性関節りウマチが 2 例であった。合併症は糖 尿症 2 例, 慢性腎不全 1 例, 肝機能障害 1 例, 悪性り ンパ腫 1 例であった，発症原因として明らかであった 
ものは関節内注射が 6 例であった。

起因菌が同定された症例は 6 例でいずれも黄色ブド ウ球菌（このうち 1 例は MRSA）であり，その他の 症例においては起因菌は同定されなかった，発症より 手術までの期間は 1 ～19 日であった。

$$
\text { V. 結果 }
$$

\section{1. 血液検查}

術前の白血球数は $8,000 \mathrm{cu} / \mathrm{mm}$ 以下が 4 例， 8,000 $\mathrm{cu} / \mathrm{mm}$ 以上が 11 例であり,この 11 例の白血球数が 正常化したのは術後 $1 \sim 15$ 日目, 平均 10.0 日目であっ た。

術前 CRP は全例陽性（>0.5）で, 13 例で陰性化 （ミ0.5）した. CRPが陰性化したのは術後 $8 \sim 55$ 日 目，平均 23.8 日目であった，悪性リンパ腫及び慢性 腎不全の症例は最終 follow up 時も CRP は陽性で あった。

術後の ESR は全例妄進していたが, 最終 follow up 時も克進していた症例が半数の 8 例存在した.

2. 創閉鎖

浸出液がなくなった時点で創縫合した 2 例を除いた 13 例で創は自然閉鎖した，創閉鎖まで要した期間は 術後 18〜42 日, 平均 31.8 日であった。

\section{3. 術後成績}

Ballard らの評価に準じて評価した，ただし Good の中でも全く正常な滕機能を有するものを Excellent とし，別に評価した。

結果は Excellent が 2 例, Good が 11 例, Fair が 2 例，Poorの症例はなかった。 Fair の症例はい ずれも 88 歳と高齢であり，関節症変化が高度で，受 傷前より機能障害を有していたものと考えられた。

4. 術後経過

全例，一次的に炎症は鎮静化し，再発を認めていな い．また後日，慢性関節リウマチの 1 例に人工膝関節 置換術を, 変形性膝関節症の 1 例 2 膝に高位脛骨骨切 り術を行った。

$$
\text { VI. 症例 }
$$

症例 1.35 歳. 男性.

1991 年 5 月初めより左膝痛出現。近医にて関節穿 刺を 3 回うけた。 5 月 20 日より腫脹が強くなり 5 月 22 日当院初診. $38^{\circ} \mathrm{C}$ 台の発熱，血液検査所見 $(\mathrm{WBC}$ 10, 200, CRP 3, 1, ESR $19 \mathrm{~mm} / \mathrm{hr}$ ), 及び関節 の著明な腫脹と局所熱感より化膿性膝関節炎と診断し, 5 月 23 日, 関節鏡視下洗浄に引き続き持続洗浄を行っ た．以後も $38^{\circ} \mathrm{C}$ 台の発熱が続き徐々にチューブがつ

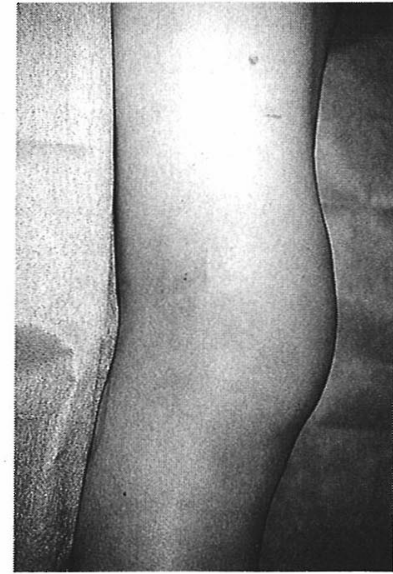

a

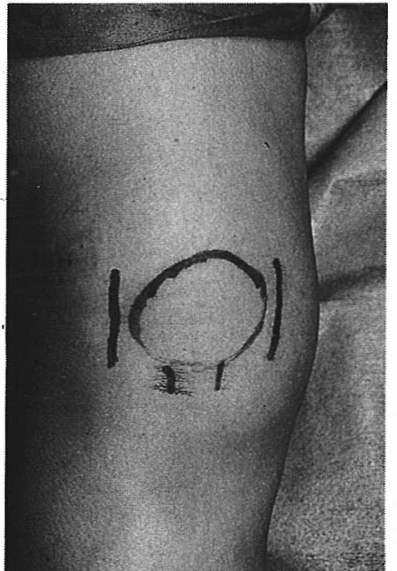

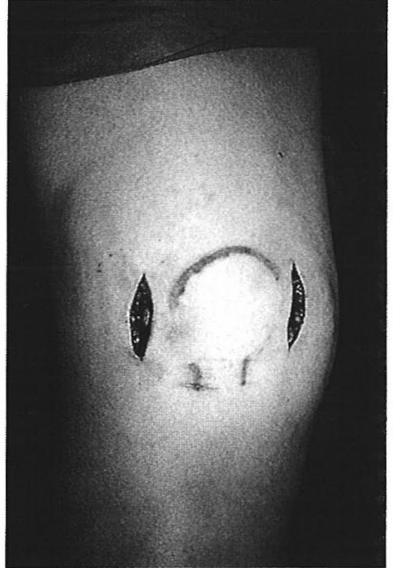

図 1 手術手技

切開洗浄後，創を開放にしたまま運動療法を開始する。

a. 術前の状態

b. 膝蓋骨および皮切のマーキング

c. 皮切 


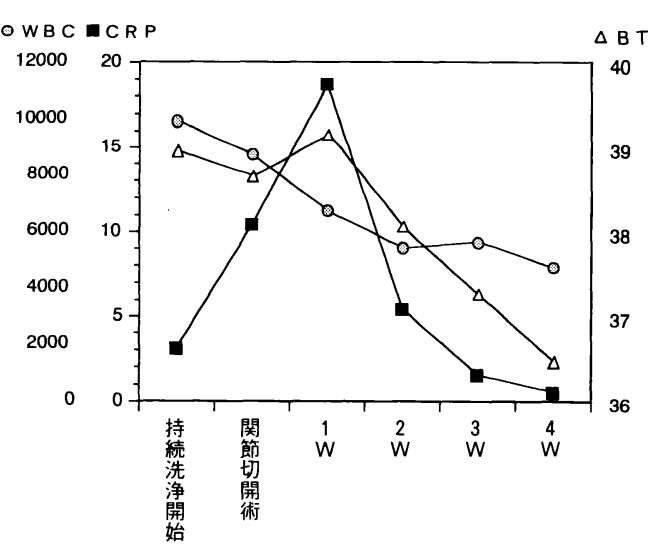

図 2 症例 1,35 歳, 男性

持続洗浄後 1 週でチューブがつまったため, 本 法を抗こなった，術後4週の血液検査ではすべ て正常化した.

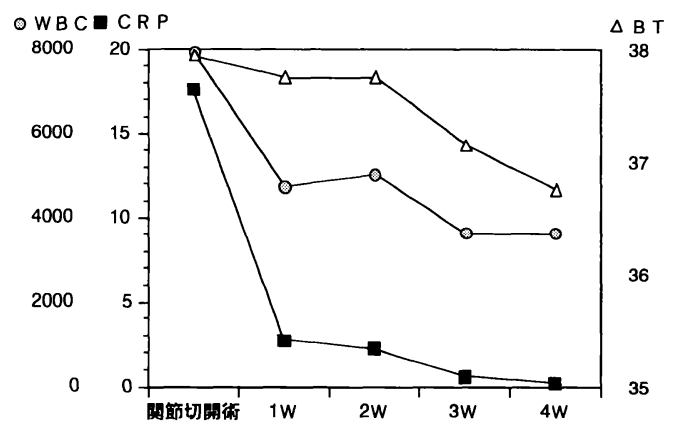

図 3 症例 2,78 歳女性

TKA 後の感染であったが, 一次的に鎮静化し た.

まり, 持続洗浄の続行が不可能となったため, 6 月 3 日本法を施行した。術後 5 日目より解発傾向がみられ 術後 4 週の 7 月 1 日の血液検査ではすべて正常化した. 創は術後 33 日目に閉鎖した. 術後 9 年目の現在, 左 膝痛は全くなく, 正座も可能である.

症例 2. 78 歳. 女性.

1996 年 12 月, 右変形性膝関節症に対し, 人工膝関 節置換術を行い, 術後経過は良好であったが, 1997 年 8 月 9 日より特に誘因なく右膝痛, 腫脹, 局所熱感 が出現した． 8 月 11 日当院受診し穿刺にて膿性の排 液を認め, 化膿性関節炎と診断し, 当日, 本法を施行 した. 術後 1 週目より解発傾向がみられ, 術後 3 週の 血液検査ではすべて正常化した。創は術後 35 日目に
閉鎖した。膝関節の可動域は $0^{\circ} \sim 105^{\circ}$ で, 発症前の 状態に回復した。

VII. 考察

化膿性膝関節炎の治療の原則は，局所の安静，排膿 と抗生剂投与であるとする意見が多いが, 局所の安静 については早期よりの可動域訓練を推める報告もあり, 意見が分かれるところである。

排膿の方法としては, 穿刺排膿法, 穿刺洗浄法, 持 続洗浄法, 関節鏡視下洗浄（及び持続洗浄）法などが ある。一般的には穿刺排膿法や穿刺洗浄法では大きな 壊死物質や debris の充分な排出が困難とされ成績不 良例が多く見られる。このため, 大量の洗浄液で洗浄 する持続洗浄法（鏡視下法も含めて）が本邦では一般 的に行われている方法(3)-5/810) であろう.

我々も当初は, 鏡視下洗浄に引き続く持続洗浄法を 用いていたが，この方法は洗浄チューブのつまりや洗 浄液のもれが頻繁に起こり，洗浄を維持するためには 二次的な処置が必要となることが多く，さらには洗浄 を途中で断念せざるを得ない場合が少なくなかった。 また，持続洗浄中に早期より可動域訓練を行うという 報告もあるが，前述の洗浄液のもれの問題もあり局所 は安静に保たざるを得ず，洗浄が長期に及ぶ場合は筋 萎縮，関節拘縮をきたした症例も経験した。また，二 次的に滑膜切除術や，鏡視下授動術を要した症例もあ り，総じて我々の鏡視下の持続洗浄による治療成績は 決して安定したものではなかった.

これらの方法に対し関節切開に引き続く解放運動 療法はWillems ${ }^{9)}$ が 1944 年に報告し Heberling, Ballard ら ${ }^{12)}$ が追試し報告した方法であり，当時 （もしかしたら現在も）化膿性関節炎の治療の原則と された『局所の安静という常識』をくつがえす方法で

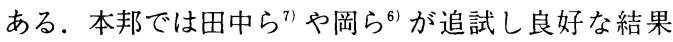
を報告している。田中らは Heberlingの文献よりの 引用として本法の利点を 5 つ挙げている77. すなわち

1）障害のある関節組織への血液供給の促進

2）充分な排膿

3）筋萎縮を防ぎ関節の炎症が消退したときに機能を 再開することが可能

4）新鮮な滑液による洗浄作用を促進

5）機能的関節の可能性の実現

である. 本法の利点はこれらのことの他に 
・手術手技が簡便である.

・術後の管理が簡便である.

ことが挙げられる. 本法の簡便さは前述した持続洗浄 法の繁雑さに比べれば明白である.

また，治療成績に関しても，我々の症例においては 全例, 一次的に炎症は鎮静化しており再発を認めてお らず，その治療率は他の方法と比べて遜色ない.

一方，関節切開法に対する否定的な意見として，関 節切開部の創閉鎖に時間がかかり関節の㓔痕性拘縮を 起こす可能性があるとの考えがある. 我々の症例にお いては創閉鎖まで平均 31.8 日とけっして短期間では なかったが，この時点ではほぼ退院可能な状態であり， 諸家の他の治療法の報告と比べても治療期間全体とし て長期間といえる程度ではなく，また瘏痕が原因と考 えられる拘縮は一例もなかった。しししながら, 本疾 患のいずれの治療法においてもあてはまることであろ うが, 術後成績は発症前の膝関節機能障害の程度に大 きく左右されると考えられた。

\section{VIII. よ め}

(1)化膿性膝関節炎 15 例 16 膝に対し開放運動療法を 行い全例，一次的に炎症は鎮静化した。

(2)本法は簡便であり治療率も極めて高く, 関節機能
も温存できる優れた方法である。

\section{参 考 文 献}

1) Ballard, C. A. et al.: The functional treatment of pyogenic arthritis of the adult knee. J Bone Joint Surg, 57-A : 1119-1123, 1975.

2) Heberling, J. A.: A review of two hundred and one case of suppurative arthritis. J Bone Joint Surg, 23 : 917-921, 1941.

3）伊藤 靖ほか：化膿性膝関節炎に対する鏡視下治療の 経験. 整形外科, 44:67-70, 1993.

4）亀山 修ほか：化膿性膝関節炎に対する鏡視下治療の 経験. 整・災外，31:195-199, 1988.

5）川嶌真人ほか：関節感染症に対する局所持続法洗浄療 法. 整·災外, $23: 865-874,1980$.

6）岡 義春ほか：化膿性膝関節炎に対する開放運動療法. 整・災外, $33: 1627-1630,1990$.

7）田中信陽ほか：化膿性膝関節炎に対する機能的治療法 の経験. 整形外科, $33: 324-328,1982$.

8). 鳥巣岳彦: 化膿性膝関節炎. 関節外科, $3: 449-454$, 1984.

9) Willems, C.: Treatment of purulent arthritis by wide arthrotomy followed by immediate active mobilization. Surg. Gynecol. Obstet., 28 : 546-554, 1919.

10）吉田孝太郎ほか：化膿性膝関節炎の観血的療法と後療 法について. 整形外科, $40: 604-611,1989$. 